
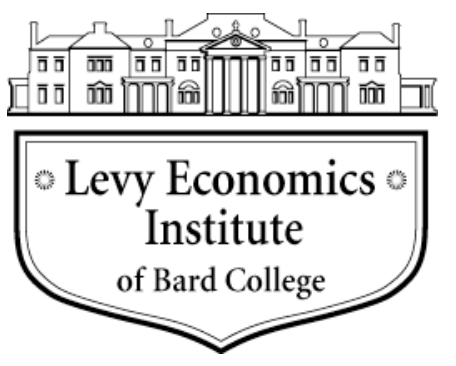

Working Paper No. 760

\title{
Indirect Domestic Value Added in Mexico's Manufacturing Exports, by Origin and Destination Sector*
}

\author{
by \\ Gerardo Fujii-Gambero \\ College of Economics, National University of Mexico \\ Rosario Cervantes-Martínez \\ University Center for Economic and Administrative Sciences, University of Guadalajara
}

\section{March 2013}

* Study sponsored by the National Council of Sciences and Technology of Mexico (CONACyT), Grant 10017, Project 152740. Authors' e-mails: fujii@unam.mx and mariac@cucea.udg.mx.

The Levy Economics Institute Working Paper Collection presents research in progress by Levy Institute scholars and conference participants. The purpose of the series is to disseminate ideas to and elicit comments from academics and professionals.

Levy Economics Institute of Bard College, founded in 1986, is a nonprofit, nonpartisan, independently funded research organization devoted to public service. Through scholarship and economic research it generates viable, effective public policy responses to important economic problems that profoundly affect the quality of life in the United States and abroad.

\author{
Levy Economics Institute \\ P.O. Box 5000 \\ Annandale-on-Hudson, NY 12504-5000 \\ http://www.levyinstitute.org
}

Copyright (C) Levy Economics Institute 2013 All rights reserved

ISSN 1547-366X 


\section{ABSTRACT}

As domestic exports usually require imported inputs, the value of exports differs from the domestic value added contained in exports. The higher the domestic value added contained in exports, the higher the domestic national income created by exports will be. In this case, exports will expand the domestic market. Therefore, exports will push economic growth in two ways: through their direct effect on aggregate demand, and through their effect on the domestic market. For these reasons, the estimate of the magnitude of the domestic value added contained in exports helps explain the capacity of exports to lead economic growth.

Domestic exports may be classified as direct and indirect exports. Direct exports are the goods sold to other countries; indirect exports are the domestically produced inputs incorporated in direct exports. The distinction between direct and indirect exports leads to a distinction between direct and indirect domestic value added contained in exports. The income of the factors directly involved in the production of exports constitutes direct domestic value added; the income contained in domestically produced inputs incorporated into exports constitutes the indirect domestic value added. Therefore, the magnitude of indirect value added depends on the density of the domestic intersectorial linkages.

The aim of this paper is to present an estimation of the domestic indirect value added contained in Mexico's manufacturing exports in two ways. The first derives from the fact that a direct exporting sector may be the vehicle through which other sectors export in an indirect way; this leads us to estimate the indirect value added contained in exports by sector of origin. The second refers to the destination of this indirect value added - that is, to the direct exporting sectors in which the value added contained in indirect exports of each sector appears.

Based on the input-output table for Mexico (National Institute of Statistics and Geography-INEGI 2008), we estimate the domestic value added contained in inputs used to produce Mexican manufacturing exports. We show separately the domestic value added from maquiladora exports and from exports produced by the rest of the manufacturing sector. In order to distinguish the indirect value added in exports by sector of origin and destination of the intermediate inputs, we work with square matrices of indirect domestic value-added multipliers. 
Keywords: Domestic Value Added in Exports; Indirect Value Added; Indirect Value Added by Sector of Origin; Indirect Value Added by Sector of Destination

JEL Classifications: C67, E01 


\section{INTRODUCTION}

A formula often found in the opening of any macroeconomics text asserts that income is equal to the sum of internal demand and net exports. Although the value of the flow of exports determines the amount of imports that it can finance and thus influences the level of income, the fact that exported goods incorporate imported intermediate goods means that the value of exports will be different from the domestic value added contained in exports. The higher the domestic value added in exports, the higher the export sector's share of national income, meaning that exports can lead to a greater expansion of the domestic market, and that exports can encourage growth both as a direct expansion of aggregate demand as well as through their effect on domestic demand. Therefore, if we know how much domestic value added is contained in exports, we can better explain the ability of the export sector to boost growth of the economy as a whole.

In the past few decades, the international fragmentation of production processes in some sectors-most noticeably in the electronics and automotive industries - has increased dramatically. Fragmentation has also widened the gap between the value of exports and domestic value added in exports, insofar as production in the electronics and automotive sectors uses a very high level of imports. In 2004, manufacturing exports had a ratio of domestic value added to exports of 47 percent in Germany, 49 percent in United States, 53 percent in Japan, and 40 percent in China (Johnson and Noguera 2011). In 2003 in Mexico, the ratio was 42 percent (Fujii and Cervantes 2013). Economic literature has begun to draw attention to the fact that some developing countries' manufacturing exports have low levels of domestic value added (United Nations Conference on Trade and Development-UNCTAD 2002). This has led to increased interest in estimating domestic value added in the exports of some countries (Breda, Cappariello, and Zizza 2007; Breda and Cappariello 2008; Daudin, Rifflart, and Schweisguth 2009).

In recent studies on this topic, domestic value added in exports has been split into direct and indirect components (Chen et al. 2005; Chen et al. 2008; Koopman, Wang, and Wei 2008; He and Zhang 2010; De la Cruz, Koopman, and Wang 2011). This division arises because domestic exports can be classified into these same categories. If direct exports are represented 
by goods sold abroad, then indirect exports are the domestically produced inputs that are included in products directly exported by the country. The magnitude of indirect exports in any given economy depends on the intensity of the domestic intersectoral linkages in its productive system. The more intense both backward and forward linkages are, the greater indirect exports will be. The division of domestic exports into direct and indirect components implies that the domestic value added contained in exports may also be split into direct and indirect elements. The former is equal to the income paid to owners of factors of production directly involved in export activity; the latter represents income contained in domestic inputs that are included in exports. Therefore, the magnitude of domestic indirect value added in exports in an economy depends on the intensity of the intersectoral linkages within the country. If two economies have the same level of exports, but one of them has denser intersectoral linkages than the other, the exports from the former will generate a higher share of national income than the latter.

During the 1950s, Hirschman (1958) pointed to the importance of sectoral diversification for economic development. This led the statistics departments of several Latin American countries in the 1960s to calculate input-output tables that were used to orient development strategies toward encouraging industrialization and import substitution in those sectors with the most intense forward (supply) and backward (demand) linkages. The relationship between economic diversification and the level of development has once again concerned economists in recent years. According to Imbs and Wacziarg (2003), a correlation exists between per capita income and sectoral diversification, taking into account either the distribution of employment or value added by sector. Poor countries show high levels of specialization; as per-capita income increases, their sectors tend to diversify, while rich countries tend to become more specialized.

The topic of domestic value added in exports is important to the Mexican economy, given Mexico's significant presence in the internationally fragmented electronics and automotive sectors. In a previous study (Fujii and Cervantes 2013), we called attention to domestic value added in Mexico's manufacturing exports and we offered an estimate of its magnitude, divided into direct and indirect components. In the current study, we shall focus on indirect value added in Mexico's manufacturing exports by means of two approaches. The first is determined by the fact that a directly exporting sector can be the vehicle by which other sectors can be indirect exporters, which leads us to trace the originating sectors of the indirect 
value added contained in the exports of the directly exporting sector. The second case refers to destination sectors, e.g., the directly exporting sectors in which the value added contained in indirect exports of each sector appears. These two perspectives allow the same total indirect value added included in exports to be distributed in two ways: the originating sectors of indirect value added contained in exports, and the destination sectors of the value added created by each sector as an indirect exporter. This brings us to consider a new approach to the problem since research into this topic provides an all-encompassing indirect value added, without breaking down the sectors in which it was created or the sectors in which it is distributed. This step allows us to observe which sectors are indirect exporters and which are being used as a vehicle of indirect exports, and the magnitudes of indirect value added by sectors that correspond to indirect exports by both origin and destination sectors.

This analysis used Mexico’s 2003 input-output table (INEGI 2008) as a baseline, which, when the economy is broken down into two sectors - the maquiladora export industry (MEI) and the domestic economy (e.g., that part of the economy that excludes the first) - allows us to understand interesting aspects of the problem, insofar as the intensity of the domestic intersectoral relationships in these two sectors is quite different.

This paper is structured as follows: In Section 1, the growing gap between export performance and the behavior of Mexico's GDP is briefly reviewed. This is at least partially explained by the low domestic value added, both direct and indirect, in manufacturing exports. Section 2 briefly describes the structure of Mexico's manufacturing exports in terms of the weight of the domestic economy and of the maquiladora export industry and the principal sectors in both. Section 3 provides a detailed methodology for breaking down domestic value added in manufacturing exports by origin and destination sectors. Section 4 outlines the distribution of indirect value added by origin and destination sectors for 2003 . The paper ends by discussing the conclusions.

\section{EXPORT DYNAMICS AND ECONOMIC GROWTH}

Since the end of the 1980s, Mexico has endeavored to maintain a growth strategy led by manufacturing exports. Trade liberalization in Mexico can be dated to 1987 when the country 
joined the General Agreement on Tariffs and Trade (GATT). Between 1992 and 2008, Mexico's total exports registered significant growth, expanding from $\$ 46.2$ billion to $\$ 291$ billion dollars in 16 years. The average annual growth of exports between 1989 and 2006 was 9.6 percent; between 1989 and 1993, it was 5.8 percent; and from 1994 to 2008, 14.1 percent. This led to a significant increase in the country's export coefficient, growing from 13 to 27 percent during 1992-2008 (see Figure 1).

Figure 1 Total exports and export coefficient

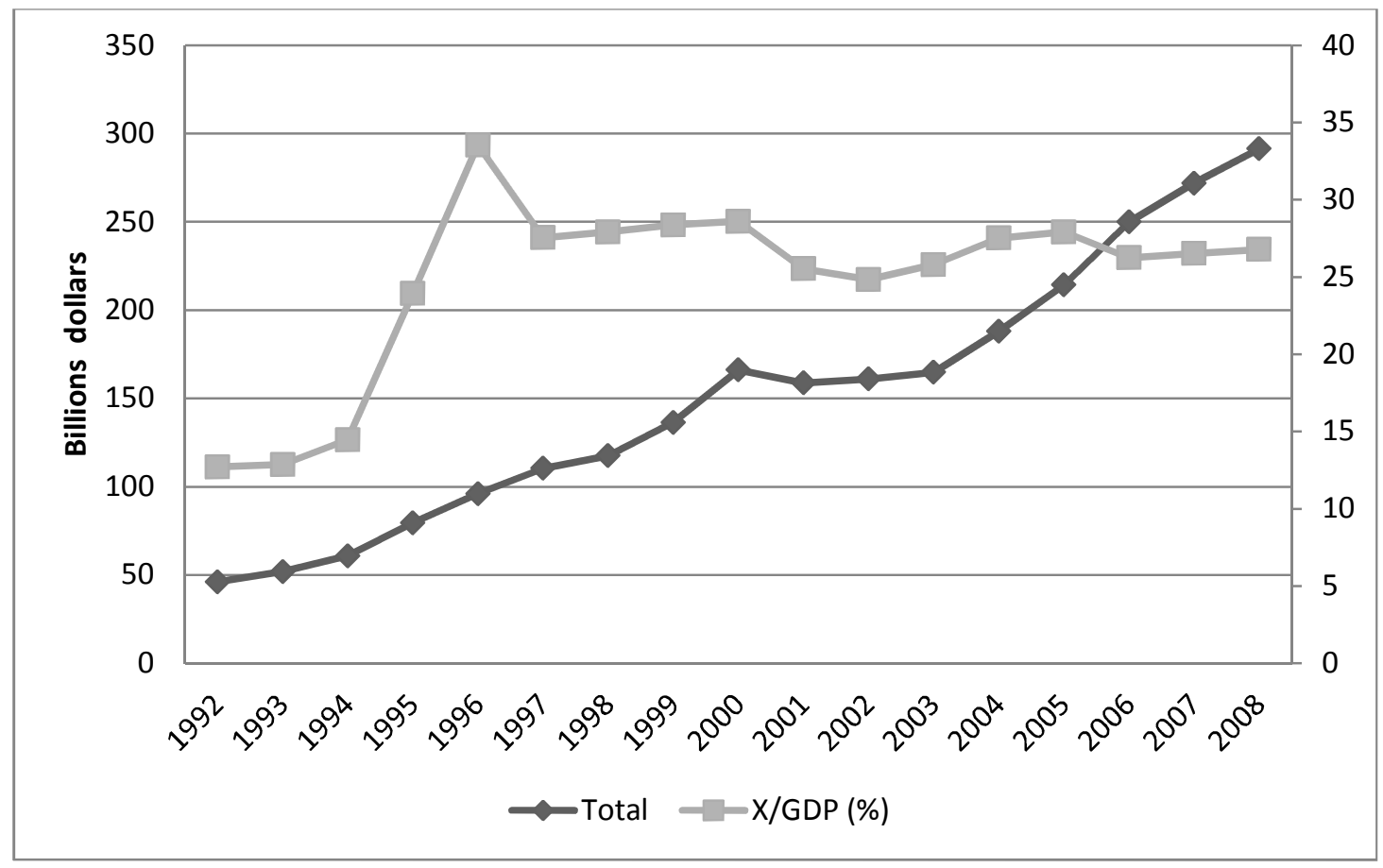

Source: Banco de México (2009)

Both Mexico's dynamic export performance and the change in the composition of export goods occurred simultaneously. Thus, in 2008, manufacturing exports grew to 231 billion dollars, equivalent to 79 percent of the country's total exports (Banco de México 2009). The composition of industrial exports by factor intensity, classified either as natural resource intensive goods, or as technology-intensive goods - whether low, medium, or high intensityshows that the most significant share was medium and high technology-intensive industrial products, given that, since the start of the 1990s, these have accounted for about 60 percent of 
the country's industrial exports (Economic Commission for Latin America and the CaribbeanECLAC 2008). Yet these figures must be viewed with caution, since they derive from the classification of the technological level of export goods: it may well be that a given country has specialized in producing a technologically simple stage of a high-technology good. This is especially important to consider in countries such as Mexico in which an important segment of manufacturing exports are produced in the context of internationally fragmented production processes.

Errors may occur if the specific manufacturing export profile of those countries that are fully integrated into the international production system is not taken into account. For example, Myro et al. (2008, 38, 40) classify Organisation for Economic Co-operation and Development (OECD) countries' manufacturing exports into three categories-advanced, intermediate and traditional — according to dynamics of demand and technological intensity. They point out that in 2005, 41 percent of Mexico's manufacturing exports were advanced, 37 percent were intermediate, and 22 percent were traditional exports. The same figures for Germany are 21, 55, and 23 percent, respectively. Japan's are 32, 55, and 13 percent. In short, these figures would seem to show that Mexico's participation in international trade is more technologically advanced, and its demand dynamic is more pronounced than that of two great exporting powers among developed countries. In addition, allowing for the sophistication of its exports (Hausmann et al. 2007), Mexico should grow faster given its level of productive specialization. We believe that this apparent situation is due to the omission of Mexico's specialization at a particular stage of production of high technology products.

Notwithstanding the extraordinary performance shown by the export manufacturing sector since the 1980s, the gap between exports and national income has continued to widen in recent decades (see Figure 2). Palma (2005) has commented on this relationship, which was particularly noticeable in the 1990s when exports grew at an average annual rate of 12.5 percent, while income grew at a rate of 3.4 percent (World Bank 2011). 
Figure 2 Mexico: GDP and exports*

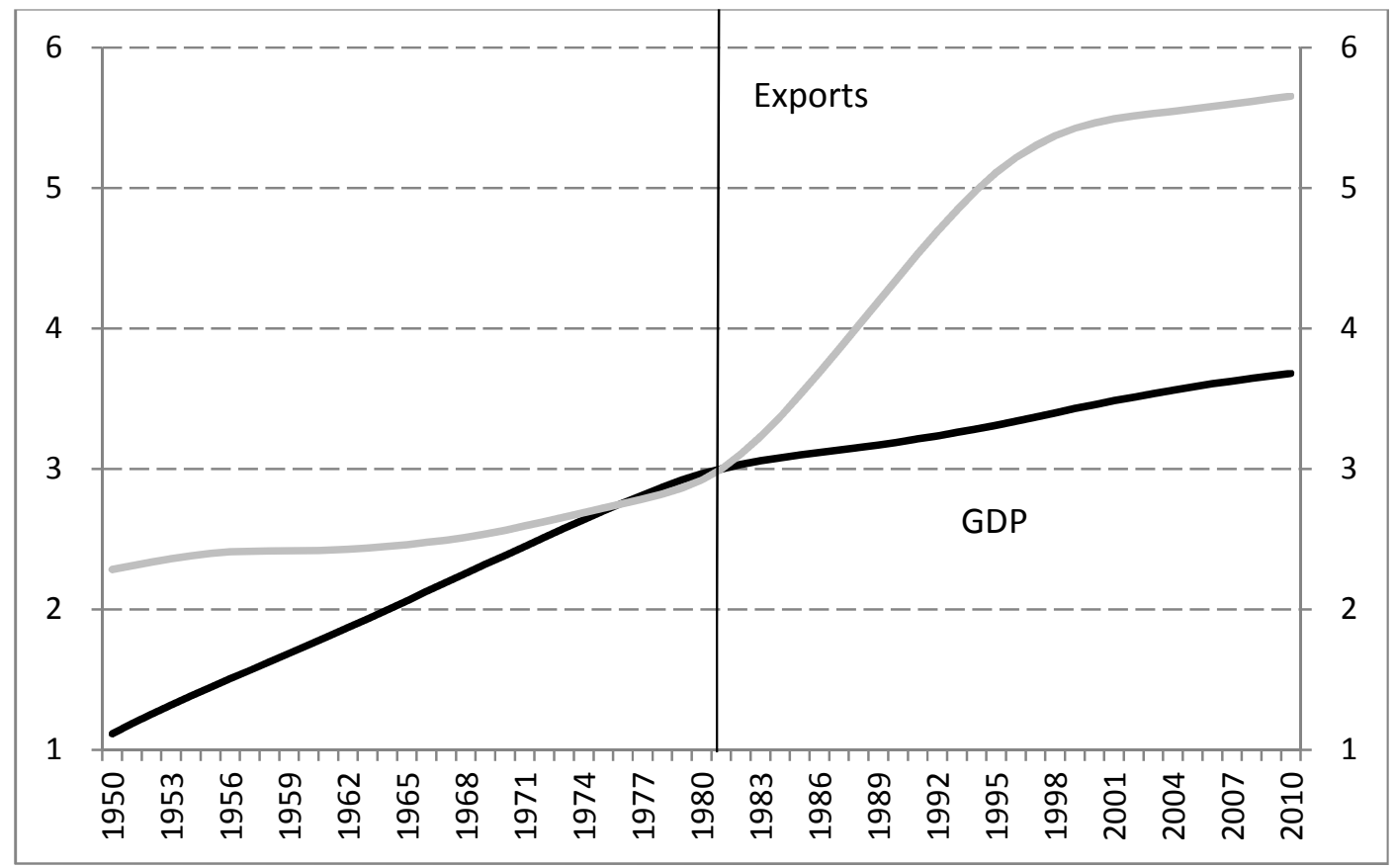

Note: *Non-oil exports. HP filtered trend lines of log GDP and log exports.

Source: INEGI (2008): Economic Information Bank for 1980-2010 GDP; Historical Statistics of Mexico for 19501979 GDP; and Mexican Petroleum-PEMEX (1988): Statistical Yearbook (for oil exports 1950-1979).

\section{MANUFACTURING EXPORTS OF THE DOMESTIC ECONOMY AND THE MAQUILADORA INDUSTRY}

The characteristics of manufacturing exports generated by the domestic economy and by the maquiladora export industry mean that the value added in each is very different, both in magnitude and with respect to that part generated directly and indirectly. Our first task here will therefore be to describe briefly the weight that both sectors have in Mexico's manufacturing exports, both globally and in the most export-relevant manufacturing sectors.

Table 1 shows the composition of the country's manufacturing exports by subsector of economic activity, with greater detail for the three sectors that contribute two-thirds of the country's manufacturing exports- the computer and electronics industry, transportation equipment, and the electrical goods industry. The table also shows whether these exports come from the maquiladora export sector or the domestic economy. Key findings include the following: 
- The largest share of manufacturing exports derives from the maquiladora industry (62 percent of the total).

- If the export sectors are ranked in three categories according to their level of integration into the economy (based on the share of exports coming from the domestic economy) high (more than 70 percent of exports come from the domestic economy); medium (between 30 and 70 percent); and low-it becomes apparent that 52 percent of Mexico's manufacturing exports originate in sectors with a low level of internal integration. At the other extreme, only 10 percent of exports originate in sectors that are strongly integrated into the domestic economy.

- Three sectors contribute the largest share of manufacturing exports: electronics (29 percent), transportation equipment (28 percent), and electrical goods ( 9 percent of the total). Taken together, they make up 66 percent of the value of Mexico's manufacturing exports.

- Yet, these sectors are radically different in terms of their degree of integration with the rest of the domestic economy: while 88 percent of the electronic industry's exports and 81 percent of the electrical goods industry's exports come from the maquiladora industry, 58 percent of the transportation equipment industry's exports is derived from the domestic economy. 
Table 1 Composition of manufacturing exports, 2003 (million Mexican pesos)

\begin{tabular}{|c|c|c|c|c|c|c|c|c|}
\hline \multirow[b]{2}{*}{ Subsector } & \multicolumn{2}{|c|}{ Total } & \multicolumn{2}{|c|}{ Domestic economy } & \multicolumn{2}{|c|}{$\begin{array}{l}\text { Maquiladora } \\
\text { Exports }\end{array}$} & \multicolumn{2}{|c|}{ Percentage } \\
\hline & Exports & $\%$ & Exports & $\%$ & Exports & $\%$ & $\begin{array}{l}\text { Domestic } \\
\text { economy }\end{array}$ & $\begin{array}{c}\text { Maquiladora } \\
\text { exports }\end{array}$ \\
\hline $\begin{array}{l}\text { Computer and } \\
\text { Electronic Product } \\
\text { Manufacturing }\end{array}$ & 385,317 & 28.9 & 47,741 & 9.4 & 337,576 & 40.8 & 12.4 & 87.6 \\
\hline $\begin{array}{l}\text { Transportation } \\
\text { Equipment } \\
\text { Manufacturing }\end{array}$ & 366,969 & 27.5 & 211,203 & 41.6 & 155,766 & 18.8 & 57.6 & 42.4 \\
\hline $\begin{array}{l}\text { Electrical } \\
\text { Equipment, } \\
\text { Appliance, and } \\
\text { Component } \\
\text { Manufacturing }\end{array}$ & 122,366 & 9.2 & 23,135 & 4.6 & 99,231 & 12 & 18.9 & 81.1 \\
\hline Subtotal & 874,651 & 65.5 & 282,078 & 55.6 & 592,573 & 71.6 & 32.3 & 67.7 \\
\hline $\begin{array}{l}\text { Rest of } \\
\text { manufacturing } \\
\text { industries }\end{array}$ & 460,514 & 34.5 & 225,015 & 44.4 & 235,499 & 28.4 & 48.9 & 51.1 \\
\hline Total exports & $1,335,165$ & 100 & 507,093 & 100 & 828,072 & 100 & 38 & 62 \\
\hline
\end{tabular}

Source: Authors' estimation based on INEGI (2008) Matriz de insumo-producto 2003

\section{METHODOLOGY}

Following the work of Koopman, Wang, and Wei (2008) and that of He and Zhang (2010), in Fujii and Cervantes (2013) we explained the methodology used to calculate the total domestic value added contained in Mexico's manufacturing exports. With data from INEGI's 2003 inputoutput tables, the matrices of value added multipliers for the domestic economy (DE) and the maquiladora export industry (MEI) are expressed by equations (1) and (2), respectively.

$$
\begin{aligned}
& M^{D E}=A_{V}^{D E}\left(I-A^{D E}\right)^{-1} \\
& \left.M^{M E I}=\left(\left(A_{V}^{D E}\left(I-A^{D E}\right)^{-1}\right) A^{M E I}\right)+A_{V}^{M E I}\right]
\end{aligned}
$$

where $M^{E I}$ is a $n \times n$ dimension matrix, whose elements $m_{i, j}^{D E}$ represent the share of domestic value added attributed to sector $i$ by unit of export in sector $j$, produced by non-maquiladora companies; $n$ is the number of branches or subsectors of the economy; $\left(I-A^{D E}\right)^{-1}$ is the known Leontief inverse matrix; and $A_{V}^{D E}$ is the diagonal matrix of value-added coefficients, whose elements in the main diagonal are obtained by dividing the value added by sector $i$ by the 
gross value of production in that same sector. Therefore, when $i=j$, the direct and indirect intra-industrial effects are obtained, all elements not found in the main diagonal represent solely indirect effects.

With regard to the effect that the maquiladora export industry exports have on the generation of domestic value added, in equation (2) the term $\left(A_{V}^{D E}\left(I-A^{D E}\right)^{-1}\right) A^{M E I}$ corresponds to the indirect effects that maquiladora industry exports have on the companies of the domestic economy. Where $A^{M E I}$ is a matrix of $n \times n$ dimensions and its elements represent the share of inputs consumed by the export sector $j$ that come from companies within the domestic economy; $A^{M E I}$ is a matrix of coefficients of domestic inputs consumed by the MEI and provided by the DE. Note that $A_{V}^{D E}\left(I-A^{D E}\right)^{-1}$ is the value-added multiplier matrix from DE. Finally, $A_{V}^{M E I}$ is a diagonal matrix of value-added coefficients from the MEI and represents the direct effects of maquiladora exports on domestic value added.

To estimate just the indirect effects of manufacturing exports on the generation of domestic value added, in equations (3) and (4) we find the "indirect value added multipliers" matrices.

$$
\begin{aligned}
& M I^{D E}=A_{V}^{D E}\left[\left(I-A^{D E}\right)^{-1}-I\right] \\
& M I^{M E I}=\left(A_{V}^{D E}\left(I-A^{D E}\right)^{-1}\right) A^{M E I}
\end{aligned}
$$

Where $M I^{D E}$ is a matrix of $n \times n$ dimensions and its elements $m i_{i, j}^{D E}$ represent indirect value added generated by sector $i$ by unit of export of sector $j$. Thus, for example, if the value of multiplier $m i_{i, j}^{D E}$ is equal to zero, this means that the sector $i$ does not produce inputs for sector $j$; in other words, the position variables represent the origin and destination sectors of the inputs, respectively.

Calculating the indirect effects on domestic value added associated with maquiladora industry exports means estimating total inputs demanded by sectors $j$ of the MEI of sectors $i$ of the DE, as if these inputs were exports by companies in the domestic economy. Thus, in equation (4), we see how, by means of the Leontief inverse, if sector $j$ of the MEI consumes one unit of input (product) that originates in sector $i$ of the DE, the production of this input, in turn, demands a certain quantity of inputs from companies in the domestic economy. So, each multiplier is the result of the product between each one of the value-added multipliers of the DE 
by the share of domestic inputs incorporated into the production of goods in each one of the MEI sectors. In equations (5) and (6), an example shows how an indirect value-added multiplier is calculated:

$$
\begin{aligned}
& m i_{11}^{D E}=v a_{1}^{D E} r_{11}^{D E}-v a_{1}^{D E} \\
& m i_{11}^{M E I}= \\
& \left(v a_{1}^{D E} r_{11}^{D E}\right) c i_{11}^{M E I}+\left(v a_{1}^{D E} r_{12}^{D E}\right) c i_{21}^{M E I}+\left(v a_{1}^{D E} r_{13}^{D E}\right) c i_{31}^{M E I}+\cdots+\left(v a_{1}^{D E} r_{1 n}^{D E}\right) c i_{n 1}^{M E I}
\end{aligned}
$$

where terms $r_{i, j}^{D E}$ are elements from the Leontief inverse matrix and represent the coefficients of input or total product requirements in the sector $i$ needed to satisfy a unit of final demand in sector $j ; v a_{i}^{D E}$ is the coefficient of value added in sector $i$ of the domestic economy; and $c i_{i j}^{M E I}$ is the coefficient of domestic inputs that sector $j$ of the maquiladora industry demands from sector $i$ of the DE.

Thus, the value of multiplier $m i_{11}^{D E}$ in equation (5) represents the quantity of value added generated by the purchase of inputs from sector 1 (origin) to produce one unit of exportable product in this same sector (destination); therefore, in the equation, only direct value added is subtracted.

On the other hand, in equation (6), the coefficient $c i_{11}^{M E I}$ shows us the share of domestic inputs that one unit of product in sector 1 (destination) of the MEI buys from sector 1 (origin) of the DE, while coefficient $c i_{21}^{M E I}$ indicates the share of domestic inputs that sector 1 of the MEI purchases from sector 2 of the DE in order to produce one unit of product, and so successively until coefficient $c i_{n 1}^{M E I}$, which indicates what the share is of domestic inputs of sector $n$ of the DE that is demanded to produce a good in sector 1 of the MEI.

Hence, in expression $\left(v a_{1}^{D E} r_{11}^{D E}\right) c i_{11}^{M E I}$, what is measured is total value added generated in sector 1 of the DE (originating sector of total inputs) by unit of exports in sector 1 of the MEI. Expression $\left(v a_{1}^{D E} r_{12}^{D E}\right) c i_{21}^{M E I}$ measures value added in sector 1 of the DE that is generated because this sector is providing inputs to sector 2 of the DE, and the latter, in turn, sells inputs to sector 1 of the MEI, which, in the end, exports all its production. In other words, the sum of all terms in equation (6) represents total value added generated in sector 1 of the DE because it provides, directly and indirectly, inputs to sector 1 of the MEI. 


\section{INDIRECT DOMESTIC VALUE ADDED IN MANUFACTURING EXPORTS BY SECTORS OF ORIGIN AND DESTINATION}

\subsection{Direct and Indirect Value Added in Manufacturing Exports}

Table 2 shows domestic value added in manufacturing exports separated into direct and indirect components. The table presents data for total manufacturing, for the domestic economy and maquiladora export industry segments from the 2003 input-output matrix, as well as for the three most important sectors in terms of their share of the country's manufacturing exports. The most important findings are:

- Domestic value added makes up 42 percent of manufacturing exports. This coefficient is significantly higher in domestic economy exports ( 75 percent) than those of the maquiladora export industry (22 percent). This means that domestic economy exports, which make up 38 percent of manufacturing exports, contribute 67 percent of the domestic value added contained in manufacturing exports. For its part, the maquiladora export industry, while accounting for 62 percent of manufacturing exports, contributes 33 percent of the domestic value added contained in manufacturing exports.

- The three sectors which make the largest contributions to manufacturing exports (66 percent of the total), contribute 54 percent of the domestic value added contained in exports. This derives from the fact that the coefficient of domestic value added with respect to exports is, in these sectors, significantly lower than for the rest of manufacturing exports: 35 vs. 56 percent. This occurs in these sectors' exports, both domestic economy exports and maquiladora industry exports. The former's coefficient is 69 percent and the latter's is 19 percent ( 81 and 22 percent for the rest of manufacturing exports in both segments, respectively).

- For all manufacturing, direct value added is equal to 23 percent of export value, while the coefficient for indirect value added is 20 percent. Further, although for the domestic economy the magnitudes are equal (37 percent), in the case of the maquiladora export industry, the two coefficients are significantly lower, especially the one that relates to indirect value added, equaling 9 percent of this sector's export value.

- With regards to the three sectors that contribute the most to manufacturing exports, the 
coefficients of indirect value added vis-à-vis exports are particularly low in the maquiladora export industry, at just 7 percent. For the electronics industry (40 percent of the maquiladora industry's exports), the coefficient is even lower (6 percent). There is a notable difference with respect to the exporting sectors of the domestic economy: the automotive industry (42 percent of domestic economy exports) has a coefficient of indirect-value-added with respect to exports of 33 percent.

Table 2 Domestic Value Added in Manufacturing Exports, 2003 (million Mexican pesos)

\begin{tabular}{|c|c|c|c|c|c|c|c|c|c|}
\hline & \multicolumn{9}{|c|}{ Total } \\
\hline & \multicolumn{2}{|c|}{ Total Value Added } & \multicolumn{2}{|c|}{$\begin{array}{l}\text { Direct Value } \\
\text { Added } \\
\end{array}$} & \multicolumn{2}{|c|}{$\begin{array}{c}\text { Indirect Value } \\
\text { Added }\end{array}$} & \multicolumn{3}{|c|}{$\begin{array}{l}\text { Domestic Value Added as } \\
\text { Percentage of Exports }\end{array}$} \\
\hline & Pesos & $\%$ & Pesos & $\%$ & Pesos & $\%$ & Total & Direct & Indirect \\
\hline $\begin{array}{l}\text { Transportation } \\
\text { Equipment } \\
\text { Manufacturing }\end{array}$ & 182,741 & 32.4 & 100,446 & 33.4 & 82,294 & 31.1 & 49.8 & 27.4 & 22.4 \\
\hline $\begin{array}{l}\text { Computer and } \\
\text { Electronic } \\
\text { Product } \\
\text { Manufacturing }\end{array}$ & 81,024 & 14.3 & 48,505 & 16.1 & 32,520 & 12.3 & 21.0 & 12.6 & 8.4 \\
\hline $\begin{array}{l}\text { Electrical } \\
\text { Equipment, } \\
\text { Appliance, and } \\
\text { Component } \\
\text { Manufacturing }\end{array}$ & 41,578 & 7.4 & 23,002 & 7.7 & 18,576 & 7.0 & 34.0 & 18.8 & 15.2 \\
\hline Subtotal & 305,343 & 54.1 & 171,953 & 57.2 & 133,390 & 50.5 & 34.9 & 19.7 & 15.3 \\
\hline $\begin{array}{l}\text { Rest of } \\
\text { manufacturing } \\
\text { industries }\end{array}$ & 259,416 & 45.9 & 128,596 & 42.8 & 130,820 & 49.5 & 56.3 & 27.9 & 28.4 \\
\hline $\begin{array}{l}\text { Total Value } \\
\text { Added }\end{array}$ & 564,759 & 100.0 & 300,549 & 100.0 & 264,210 & 100.0 & 42.3 & 22.5 & 19.8 \\
\hline & \multicolumn{9}{|c|}{ Domestic economy } \\
\hline & \multicolumn{2}{|c|}{ Total Value Added } & \multicolumn{2}{|c|}{$\begin{array}{l}\text { Direct Value } \\
\text { Added } \\
\end{array}$} & \multicolumn{2}{|c|}{$\begin{array}{c}\text { Indirect Value } \\
\text { Added } \\
\end{array}$} & \multicolumn{3}{|c|}{$\begin{array}{c}\text { Domestic Value Added as } \\
\text { Percentage of Exports }\end{array}$} \\
\hline $\begin{array}{l}\text { Transportation } \\
\text { Equipment } \\
\text { Manufacturing }\end{array}$ & 144,396 & 38.1 & 74,718 & 39.4 & 69,678 & 36.8 & 68.4 & 35.4 & 33.0 \\
\hline $\begin{array}{l}\text { Computer and } \\
\text { Electronic } \\
\text { Product } \\
\text { Manufacturing }\end{array}$ & 33,812 & 8.9 & 20,878 & 11.0 & 12,934 & 6.8 & 70.8 & 43.7 & 27.1 \\
\hline
\end{tabular}




\begin{tabular}{|c|c|c|c|c|c|c|c|c|c|}
\hline $\begin{array}{l}\text { Electrical } \\
\text { Equipment, } \\
\text { Appliance, and } \\
\text { Component } \\
\text { Manufacturing }\end{array}$ & 17,551 & 4.6 & 9,398 & 5.0 & 8,153 & 4.3 & 75.9 & 40.6 & 35.2 \\
\hline Subtotal & 195,759 & 51.7 & 104,993 & 55.4 & 90,766 & 47.9 & 69.4 & 37.2 & 32.2 \\
\hline $\begin{array}{l}\text { Rest of } \\
\text { manufacturing } \\
\text { industries }\end{array}$ & 183,185 & 48.3 & 84,452 & 44.6 & 98,734 & 52.1 & 81.4 & 37.5 & 43.9 \\
\hline $\begin{array}{l}\text { Total Value } \\
\text { Added }\end{array}$ & 378,945 & 100.0 & 189,445 & 100.0 & 189,499 & 100.0 & 74.7 & 37.4 & 37.4 \\
\hline & \multicolumn{9}{|c|}{ Maquiladora Exports } \\
\hline & \multicolumn{2}{|c|}{ Total Value Added } & \multicolumn{2}{|c|}{$\begin{array}{l}\text { Direct Value } \\
\text { Added }\end{array}$} & \multicolumn{2}{|c|}{$\begin{array}{c}\text { Indirect Value } \\
\text { Added }\end{array}$} & \multicolumn{3}{|c|}{$\begin{array}{l}\text { Domestic Value Added as } \\
\text { Percentage of Exports }\end{array}$} \\
\hline $\begin{array}{l}\text { Transportation } \\
\text { Equipment } \\
\text { Manufacturing }\end{array}$ & 38,344 & 20.6 & 25,728 & 23.2 & 12,616 & 16.9 & 24.6 & 16.5 & 8.1 \\
\hline $\begin{array}{l}\text { Computer and } \\
\text { Electronic } \\
\text { Product } \\
\text { Manufacturing }\end{array}$ & 47,212 & 25.4 & 27,627 & 24.9 & 19,585 & 26.2 & 14.0 & 8.2 & 5.8 \\
\hline $\begin{array}{l}\text { Electrical } \\
\text { Equipment, } \\
\text { Appliance, and } \\
\text { Component } \\
\text { Manufacturing }\end{array}$ & 24,027 & 12.9 & 13,604 & 12.2 & 10,423 & 14.0 & 24.2 & 13.7 & 10.5 \\
\hline Subtotal & 109,584 & 59.0 & 66,960 & 60.3 & 42,624 & 57.1 & 18.5 & 11.3 & 7.2 \\
\hline $\begin{array}{l}\text { Rest of } \\
\text { manufacturing } \\
\text { industries }\end{array}$ & 76,231 & 41.0 & 44,144 & 39.7 & 32,087 & 42.9 & 32.4 & 18.7 & 13.6 \\
\hline $\begin{array}{l}\text { Total Value } \\
\text { Added }\end{array}$ & 185,815 & 100.0 & 111,104 & 100.0 & 74,711 & 100.0 & 22.4 & 13.4 & 9.0 \\
\hline
\end{tabular}

Source: Authors' estimation based on INEGI (2008, Matriz de insumo-producto 2003)

\subsection{Indirect Value Added in Manufacturing Exports by Sector of Origin}

Table 3 shows data from indirect value added in manufacturing exports (total, domestic economy, and maquiladora export industry) by the value-added sector of origin. These data represent total exports and the three sectors that contribute the largest share to total exports. For the manufacturing industry as a whole, the most relevant data in the table are the following:

- 78 percent of the indirect value added in manufacturing exports originates in non- 
manufacturing sectors. In other words, backward linkages in manufacturing exports show greater intensity with non-manufacturing sectors than within manufacturing.

- Those sectors that together contribute 66 percent of manufacturing exports contain 51 percent of the indirect value added in those exports, while exports from the rest of manufacturing contain 49 percent.

- Of these three sectors, transportation equipment exports have the most intense backward linkages with the rest of the domestic economy: 31 percent of indirect value added embedded in exports is contained in this sector's exports, while electronic industry exports, which contribute 29 percent of the total (slightly more than transportation equipment exports), contain only 12 percent of the total.

- In these three sectors (as is the case for total manufacturing exports), the largest portion of indirect value added of manufacturing origin contained in their exports is intrasectoral. In the transportation equipment sector, this share reaches 47 percent. When dividing industry exports into their two components, the domestic economy and maquiladora export industry, the following picture emerges:

- 72 percent of the indirect value added in manufacturing exports is found in domestic economy exports, making up 38 percent of these exports. Therefore, maquiladora industry exports, which contribute the largest part of industrial exports, are responsible for only 28 percent of the indirect value added in exports.

- In the two segments, as is the case for manufacturing as a whole, the largest portion of indirect value added in exports comes from non-manufacturing sectors (77 and 82 percent in the domestic economy and in the maquiladora export industry, respectively).

- In the domestic economy, the three sectors that contribute 56 percent of its exports contain 48 percent of indirect value added in exports, while the exports from the rest of manufacturing (44 percent of the manufacturing exports from the domestic economy) contain 52 percent. In the maquiladora industry, 57 percent of the indirect value added in its exports is found in the exports of these three sectors.

- In the domestic economy, transportation equipment exports contain the largest portion of indirect value added in these sectors' exports: 77 percent, the largest portion of which originates in non-manufacturing sectors (73 percent). In turn, 51 percent of indirect 
value added of intra-manufacturing origin is intrasectoral.

- In the maquiladora industry, 26 percent of the indirect value added in its exports is embedded in the exports of the electronics industry (representing 41 percent of the maquiladora exports). It is also true that in this case, the largest portion of this value added comes from non-manufacturing inputs. 
Table 3 Indirect value added contained in manufacturing exports, 2003 (million Mexican pesos)

\begin{tabular}{|c|c|c|c|c|c|c|c|c|c|c|c|c|}
\hline & \multicolumn{11}{|c|}{ Total Manufacturing } & \multirow[b]{2}{*}{$\%$} \\
\hline & $\begin{array}{c}\text { Transportation } \\
\text { Equipment } \\
\text { Manufacturing } \\
\end{array}$ & $\%$ & $\begin{array}{l}\text { Computer and } \\
\text { Electronic } \\
\text { Product } \\
\text { Manufacturing } \\
\end{array}$ & $\%$ & $\begin{array}{c}\text { Electrical } \\
\text { Equipment, } \\
\text { Appliance, and } \\
\text { Component } \\
\text { Manufacturing }\end{array}$ & $\%$ & Subtotal & $\%$ & $\begin{array}{c}\text { Rest of } \\
\text { Manufacturing } \\
\text { Industries } \\
\end{array}$ & $\%$ & $\begin{array}{l}\text { Total Value } \\
\text { Added through } \\
\text { Intermediate } \\
\text { Demand } \\
\end{array}$ & \\
\hline $\begin{array}{l}\text { Transportation } \\
\text { Equipment } \\
\text { Manufacturing } \\
\end{array}$ & $\mathbf{9 , 7 3 8}$ & 11.8 & 85 & 0.3 & 82 & 0.4 & 9,905 & 7.4 & 434 & 0.3 & 10,338 & 3.9 \\
\hline $\begin{array}{l}\text { Computer and } \\
\text { Electronic Product } \\
\text { Manufacturing }\end{array}$ & 564 & 0.7 & $\mathbf{1 , 8 8 6}$ & 5.8 & 151 & 0.8 & 2,602 & 2.0 & 309 & 0.2 & 2,911 & 1.1 \\
\hline $\begin{array}{l}\text { Electrical } \\
\text { Equipment, } \\
\text { Appliance, and } \\
\text { Component } \\
\text { Manufacturing }\end{array}$ & 164 & 0.2 & 56 & 0.2 & 233 & 1.3 & 454 & 0.3 & 162 & 0.1 & 615 & 0.2 \\
\hline Subtotal & 10,467 & 12.7 & 2,027 & 6.2 & 467 & 2.5 & 12,960 & 9.7 & 904 & 0.7 & 13,865 & 5.2 \\
\hline $\begin{array}{l}\text { Rest of } \\
\text { Manufacturing } \\
\text { Industries } \\
\end{array}$ & 10,267 & 12.5 & 4,862 & 15.0 & 4,130 & 22.2 & 19,259 & 14.4 & 24,220 & 18.5 & 43,479 & 16.5 \\
\hline $\begin{array}{l}\text { Total Value Added } \\
\text { through } \\
\text { Intermediate } \\
\text { Consumption }\end{array}$ & 20,734 & 25.2 & 6,888 & 21.2 & 4,597 & 24.7 & 32,219 & 24.2 & 25,124 & 19.2 & 57,344 & 21.7 \\
\hline $\begin{array}{l}\text { Non- } \\
\text { manufacturing } \\
\text { Value Added } \\
\end{array}$ & 61,560 & 74.8 & 25,631 & 78.8 & 13,979 & 75.3 & 101,171 & 75.8 & 105,696 & 80.8 & 206,867 & 78.3 \\
\hline $\begin{array}{l}\text { Total Indirect } \\
\text { Value Added on } \\
\text { Manufacturing } \\
\text { Exports }\end{array}$ & 82,294 & 100.0 & 32,520 & 100.0 & 18,576 & 100.0 & 133,390 & 100.0 & 130,820 & 100.0 & 264,210 & 100.0 \\
\hline
\end{tabular}


Domestic Economy

\begin{tabular}{|c|c|c|c|c|c|c|c|c|c|c|c|c|}
\hline & \multicolumn{12}{|c|}{ Domestic Economy } \\
\hline & $\begin{array}{l}\text { Transportation } \\
\text { Equipment } \\
\text { Manufacturing } \\
\end{array}$ & $\%$ & $\begin{array}{l}\text { Computer and } \\
\text { Electronic } \\
\text { Product } \\
\text { Manufacturing }\end{array}$ & $\%$ & $\begin{array}{c}\text { Electrical } \\
\text { Equipment, } \\
\text { Appliance, and } \\
\text { Component } \\
\text { Manufacturing }\end{array}$ & $\%$ & Subtotal & $\%$ & $\begin{array}{c}\text { Rest of } \\
\text { Manufacturing } \\
\text { Industries }\end{array}$ & $\%$ & $\begin{array}{c}\text { Total Value Added } \\
\text { through } \\
\text { Intermediate } \\
\text { Demand }\end{array}$ & $\%$ \\
\hline $\begin{array}{l}\text { Transportation } \\
\text { Equipment } \\
\text { Manufacturing } \\
\end{array}$ & 9,640 & 13.8 & 36 & 0.3 & 37 & 0.4 & 9,713 & 10.7 & 331 & 0.3 & 10,044 & 5.3 \\
\hline $\begin{array}{l}\text { Computer and } \\
\text { Electronic Product } \\
\text { Manufacturing }\end{array}$ & 413 & 0.6 & 1,340 & 10.4 & 32 & 0.4 & 1,785 & 2.0 & 123 & 0.1 & 1,908 & 1.0 \\
\hline $\begin{array}{l}\text { Electrical } \\
\text { Equipment, } \\
\text { Appliance, and } \\
\text { Component } \\
\text { Manufacturing }\end{array}$ & 109 & 0.2 & 42 & 0.3 & 114 & 1.4 & 265 & 0.3 & 88 & 0.1 & 353 & 0.2 \\
\hline Subtotal & 10,162 & 14.6 & 1,418 & 11.0 & 182 & 2.2 & 11,763 & 13.0 & 542 & 0.5 & 12,305 & 6.5 \\
\hline $\begin{array}{l}\text { Rest of } \\
\text { Manufacturing } \\
\text { Industries }\end{array}$ & 8,722 & 12.5 & 1,914 & 14.8 & 2,227 & 27.3 & 12,864 & 14.2 & 18,553 & 18.8 & 31,417 & 16.6 \\
\hline $\begin{array}{l}\text { Total } \\
\text { Manufacturing } \\
\text { Value Added } \\
\text { through } \\
\text { Intermediate } \\
\text { Consumption } \\
\end{array}$ & 18,885 & 27.1 & 3,332 & 25.8 & 2,409 & 29.6 & 24,626 & 27.1 & 19,096 & 19.3 & 43,722 & 23.1 \\
\hline $\begin{array}{l}\text { Non- } \\
\text { manufacturing } \\
\text { Value Added } \\
\end{array}$ & 50,794 & 72.9 & 9,602 & 74.2 & 5,744 & 70.4 & 66,140 & 72.9 & 79,638 & 80.7 & 145,778 & 76.9 \\
\hline $\begin{array}{l}\text { Total Indirect } \\
\text { Value Added on } \\
\text { Manufacturing } \\
\text { Exports }\end{array}$ & 69,678 & 100.0 & 12,934 & 100.0 & 8,153 & 100.0 & 90,766 & 100.0 & 98,734 & 100.0 & 189,499 & 100.0 \\
\hline
\end{tabular}




\begin{tabular}{|c|c|c|c|c|c|c|c|c|c|c|c|c|}
\hline & \multicolumn{12}{|c|}{ Maquiladora Exports } \\
\hline & $\begin{array}{l}\text { Transportation } \\
\text { Equipment } \\
\text { Manufacturing } \\
\end{array}$ & $\%$ & $\begin{array}{l}\text { Computer and } \\
\text { Electronic } \\
\text { Product } \\
\text { Manufacturing } \\
\end{array}$ & $\%$ & $\begin{array}{c}\text { Electrical } \\
\text { Equipment, } \\
\text { Appliance, and } \\
\text { Component } \\
\text { Manufacturing } \\
\end{array}$ & $\%$ & Subtotal & $\%$ & $\begin{array}{c}\text { Rest of } \\
\text { Manufacturing } \\
\text { Industries } \\
\end{array}$ & $\%$ & $\begin{array}{l}\text { Total Value } \\
\text { Added through } \\
\text { Intermediate } \\
\text { Demand } \\
\end{array}$ & $\%$ \\
\hline $\begin{array}{l}\text { Transportation } \\
\text { Equipment } \\
\text { Manufacturing } \\
\end{array}$ & 98 & 0.8 & 48 & 0.2 & 46 & 0.4 & 192 & 0.5 & 102 & 0.3 & 295 & 0.4 \\
\hline $\begin{array}{l}\text { Computer and } \\
\text { Electronic Product } \\
\text { Manufacturing }\end{array}$ & 151 & 1.2 & 546 & 2.8 & 120 & 1.1 & 817 & 1.9 & 186 & 0.6 & 1,003 & 1.3 \\
\hline $\begin{array}{l}\text { Electrical } \\
\text { Equipment, } \\
\text { Appliance, and } \\
\text { Component } \\
\text { Manufacturing }\end{array}$ & 55 & 0.4 & 14 & 0.1 & 119 & 1.1 & 188 & 0.4 & 74 & 0.2 & 262 & 0.4 \\
\hline Subtotal & 305 & 2.4 & 609 & 3.1 & 285 & 2.7 & 1,198 & 2.8 & 362 & 1.1 & 1,560 & 2.1 \\
\hline $\begin{array}{l}\text { Rest of } \\
\text { Manufacturing } \\
\text { Industries }\end{array}$ & 1,545 & 12.2 & 2,947 & 15.0 & 1,903 & 18.3 & 6,395 & 15.0 & 5,667 & 17.7 & 12,062 & 16.1 \\
\hline $\begin{array}{l}\text { Total } \\
\text { Manufacturing } \\
\text { Value Added } \\
\text { through } \\
\text { Intermediate } \\
\text { Consumption }\end{array}$ & 1,850 & 14.7 & 3,556 & 18.2 & 2,188 & 21.0 & 7,593 & 17.8 & 6,029 & 18.8 & 13,622 & 18.2 \\
\hline $\begin{array}{l}\text { Non- } \\
\text { manufacturing } \\
\text { Value Added }\end{array}$ & 10,766 & 85.3 & 16,029 & 81.8 & 8,235 & 79.0 & $\mathbf{3 5 , 0 3 1}$ & 82.2 & 26,058 & 81.2 & 61,089 & 81.8 \\
\hline $\begin{array}{l}\text { Total Indirect } \\
\text { Value Added on } \\
\text { Manufacturing } \\
\text { Exports }\end{array}$ & 12,616 & 100.0 & $\mathbf{1 9 , 5 8 5}$ & 100.0 & 10,423 & 100.0 & 42,624 & 100.0 & $\mathbf{3 2 , 0 8 7}$ & 100.0 & 74,711 & 100.0 \\
\hline
\end{tabular}

Source: Authors"' estimation based on INEGI (2008, Matriz de insumo-producto 2003) 


\subsection{Indirect Value Added in Manufacturing Exports by Sector of Destination}

As previously discussed, the expression "indirect value added by sector of destination" refers to that value added produced by a sector that is not contained in its direct exports. Instead, this indirect value-added accrues to the value added in the exports of another sector, as indirect value added contained in that sector's exports. A horizontal reading of Table 3 reveals the distribution by final-export sectors of value added generated by indirect exports. What is immediately noticeable is that the distribution of indirect domestic value added in manufacturing exports is radically different depending on whether it is an originating or destination sector. In the three sectors that we have specified, the value added contained in their exports but with origin in other sectors of the economy is significantly greater than the value-added in these three sectors and destined for other directly exporting sectors. For example, while exports of transportation equipment contain 82.3 billion pesos of value added with origin in other sectors of the economy, only 10.3 billion pesos of value added created by this sector ended up in other directly exporting sectors. These sectors' small role as indirect exporters is the result of the country's export specialization in these branches, and illustrates that finished goods exports have a significant role in these branches. If we also consider the case of the electronics sector, where the indirect value added of domestic origin contained in its exports is small, we have an example of a leading exporting sector with weak forward and backward internal linkages. Given that this sector is basically made up of the maquiladora export industry, it is worth looking closely at the indirect value added data for this sector. The value added generated in other sectors that is incorporated in the exports of the maquiladora electronics industry is almost 20 billion pesos, of which only 18 percent has its origin in manufacturing. This attests to the fact that the parts and components used by the electronics industry located in Mexico are essentially imported. On the other hand, the domestic value added contained in the exports of other sectors but which originate from the domestic electronics industry is only 1 billion pesos, indicating that it is a sector that basically produces and exports finished goods. Summarizing, we see that the domestic value added in exports from the sector that contributes 41 percent of sales abroad of the maquiladora industry is largely direct (59 percent). We also see low levels of domestic value added originating in manufacturing and being included in electronic exports, in addition to the fact that the sector is not a significant provider of parts and components for other sectors of domestic industry. 
Mexico's particular export specialization can be observed in the breakdown of export data into parts and components on the one hand, and finished goods on the other, as per the UN's COMTRADE Revision 2, Section 7-Machinery and Transportation Equipment (United Nations-UN 2010). Table 4 shows exports of this sector, which accounted for 74 percent of the country's manufacturing exports in 2010, as classified into these two types of goods. The same table details the information for products in Section 7 at the four-digit level. The most relevant conclusions from this information are the following:

- Considering the entire section, 73 percent of exports are finished goods.

- Breaking exports down at a the two-digit level and regrouping them in the six divisions that contribute 97 percent of the section's exports, we see that 74 percent of these are finished goods, rising to 96 percent in the case of Division 75-Office Machines.

- At the three-digit level, 71 percent of the groups that contribute 72 percent of exports are finished goods.

- This is basically the same situation that we observe if we analyze exports at the fourdigit level. Six subgroups contribute 55 percent of Section 7 exports, 72 percent of which are finished goods.

Table 4 Exports composition: Final goods and parts and components (percentages)

\begin{tabular}{|c|c|c|c|}
\hline & $\begin{array}{c}\% \text { of } \\
\text { Section's } 7 \\
\text { exports }\end{array}$ & $\begin{array}{c}\text { Final Goods } \\
(\%)\end{array}$ & $\begin{array}{c}\text { Parts and } \\
\text { Components } \\
(\%)\end{array}$ \\
\hline \multicolumn{4}{|l|}{ Section } \\
\hline \multicolumn{4}{|l|}{ 7. Machinery and transport equipment } \\
\hline $\begin{array}{l}\text { Total } \\
\text { Divisions }\end{array}$ & 100 & 73 & 27 \\
\hline 71. Power generating machinery and equipment & 7 & 57 & 43 \\
\hline 74. General industrial machinery and equipment, nes, and parts of nes & 7 & 91 & 9 \\
\hline 75. Office machines and automatic data processing equipment & 10 & 96 & 4 \\
\hline 76. Telecommunications, sound recording, and reproducing equipment & 22 & 64 & 36 \\
\hline 77. Electric machinery, apparatus, and appliances, nes, and parts of nes & 18 & 76 & 24 \\
\hline 78. Road vehicles & 33 & 73 & 27 \\
\hline Sum & 97 & 74 & 26 \\
\hline
\end{tabular}




\begin{tabular}{|c|c|c|c|}
\hline Groups & & & \\
\hline 752. Automatic data processing machines and units thereof & 9 & 100 & 0 \\
\hline 761. Television receivers & 13 & 100 & 0 \\
\hline 764. Telecommunication equipment, nes; parts and accessories of nes & 8 & 0 & 100 \\
\hline 772. Electrical apparatus for making and breaking electrical circuits & 4 & 0 & 100 \\
\hline 773. Equipment for distribution of electricity & 4 & 100 & 0 \\
\hline 778. Electrical machinery and apparatus, nes & 4 & 96 & 4 \\
\hline 781. Passenger motor vehicles (excluding buses) & 15 & 100 & 0 \\
\hline 782. Lorries and special purposes motor vehicles & 7 & 100 & 0 \\
\hline 784. Motor vehicle parts and accessories, nes & 9 & 0 & 100 \\
\hline $\begin{array}{l}\text { Sum } \\
\text { Subgroups }\end{array}$ & 72 & 71 & 29 \\
\hline 7523. Complete digital central processing units; digital processors & 5 & 100 & 0 \\
\hline 7611. Television receivers, color & 13 & 100 & 0 \\
\hline 7643. Television, radio broadcasting; transmitters, etc. & 6 & 0 & 100 \\
\hline 7810. Passenger motor vehicles (excluding buses) & 15 & 100 & 0 \\
\hline 7821. Motor vehicles for transport of goods or materials & 7 & 100 & 0 \\
\hline 7849. Other parts and accessories, for vehicles of headings $722,781-783$ & 9 & 0 & 100 \\
\hline Sum & 55 & 72 & 28 \\
\hline
\end{tabular}

Source: Authors' calculations based on UN COMTRADE, SITC Rev. 2 (UN 2010)

\section{CONCLUSIONS}

1. The bulk of manufactured exports come from sectors that contribute relatively little to that part of national income derived from exports.

2. The largest share of domestic value added in exports is direct, which indicates that linkages between the exporting sectors and the rest of the economy are relatively weak. The maquiladora export industry, in particular, stands out in this regard.

3. The largest share of indirect value added in manufactured exports has its origin in nonmanufacturing sectors, indicating that, to a large extent, parts and components originate as imports.

4. Manufacturing industry exports are predominantly direct in nature, meaning that basically they are not working as a vehicle for the indirect exports of other sectors and 
branches. This confirms the country's tremendous export specialization in the production of finished goods. In other words, if the backward linkages between exports and the rest of manufacturing are weak, forward linkages are even more tenuous. 


\section{REFERENCES}

Bank of Mexico. 2009. 2008 Annual Report. http://www.banxico.org.mx/publicaciones-ydiscursos/publicaciones/informes-periodicos/anual/\%7BE2479C99-47CB-19B8-92A7D011876E8FCA\%7D.pdf

Breda, E. and R. Cappariello. 2008. "A Tale of Two Bazaar Economies: An Input-Output Analysis of Germany and Italy.” Rome, Italy: Bank of Italy, Economics and Financial Statistics Department.

Breda, E., R. Cappariello, and R. Zizza. 2007. "Measures of the External Trade Impulse to Economic Growth: How Relevant Is the Internationalization of Production?" Rome, Italy: Bank of Italy, Economic Research Department.

ECLAC. 2008. Panorama of the Integration of Latin America and the Caribbean, 2007. Santiago, Chile: Division of International Trade and Integration (ECLAC).

Chen, X., L. K. Cheng, K. C. Fung, and L. J. Lau. 2005. "The Estimation of Domestic Value Added and Employment Induced by Exports: An Application to Chinese Exports to the United States." Paper presented at the 2005 American Economic Association Meeting, Philadelphia, PA, January 7-9.

Chen, X., L. K. Cheng, K. C. Fung, L. J. Lau, Y. Sung, C. Yang, K. Zhuy, and Z. Tang. 2008. "Domestic Value Added and Employment Generated by Chinese Exports: A Quantitative Estimation," MPRA paper No. 15663. Munich Personal RePEc Archive.

Daudin, G., C. Rifflart, and D. Schweisguth. 2009. "Who Produces for Whom in the World Economy." Working Paper No. 2009-18. Paris, France: Observatoire francais des conjonctures économiques.

De la Cruz, J. R. Koopman, and Z. Wang. 2011. "Estimating Foreign Value-Added in Mexico's Manufacturing Exports.” Working Paper No. 2011-04A. Washington, DC: US International Trade Commission, Office of Economics.

Fujii, G. and R. Cervantes. 2013. "Valor añadido en las exportaciones manufactureras de México." CEPAL Review 110.

He, D. and W. Zhang. 2010. "How Dependent Is the Chinese Economy on Exports and in What Sense Has Its Growth Been Export-led?” Journal of Asian Economics 21: 87-104.

Hirschman, A. 1958. The Strategy of Economic Development. New Haven, CT: Yale University Press.

Hausmann, R., J. Hwang, and D. Rodrik. "What You Export Matters." Journal of Economic Growth 12: 1-25. 
Imbs, J. and R. Wacziard. 2003. "Stages of Diversification." American Economic Review 93(1): 63-86.

INEGI. 2008. Matriz de insumo-producto de México 2003. http://www.inegi.org.mx/est/contenidos/proyectos/scn/c_anuales/matrizinsumo/default.as px

Johnson, R. and G. Noguera. 2011. "The Value-Added Content of Trade.” VOX, June 7. http://www.voxeu.org/article/value-added-content-trade-new-insights-us-chinaimbalance

Koopman, R., Z. Wang, and S.-J. Wei. 2008. "How Much of Chinese Exports Is Really Made in China? Assessing Domestic Value-Added When Processing Trade Is Pervasive." Working Paper 14109. Cambridge, MA: National Bureau of Economic Research.

Myro Sánchez, R., C. M. Fernández-Otheo, L. Labrador Salas, A. B. Baides Tudela, Mª E. Álvarez López, and J. Vega Crespo. 2008. Globalización y deslocalización. Importancia y efectos para la industria española, Madrid, Spain: Ministerio de Industria, Turismo y Comercio.

Palma, J. G. 2005. “The Seven 'Stylized Facts' of the Mexican Economy since Trade Liberalization and NAFTA." Industrial and Corporate Change 14(6): 942-91.

PEMEX. 1988. Statistical Yearbook 1988. http://www.ri.pemex.com/files/content/anuario_1988.pdf

UN. 2010. United Nations Commodity Trade Statistics Database: Machinery and Transport Equipment, Revision 2. http://comtrade.un.org/db/mr/rfCommoditiesList.aspx?px=S2\&cc=7

UNCTAD. 2002. Trade and Development Report, 2002. New York, NY and Geneva, Switzerland: United Nations Conference on Trade and Development.

World Bank. 2011. World DataBank. http://databank.worldbank.org/data/home.aspx 